result, first in Ukraine and then in Muscovite Rus' the conditions arose for the assimilation and development of the notion of a "simple tongue," which was of extraordinary importance for the history of Slavic literary culture.

\title{
5. Linguistic "Simplicity" and the Means of Its Realization
}

Traditional Slavic book culture confronted the idea of linguistic "simplicity" in the sixteenth century. Although the issue of the comprehensibility of bookish texts could have been posed earlier it was in this century that it acquired fundamental importance and became a motivating factor in linguistic change in the framework of Slavia Orthodoxa. It entered into complex interaction with other factors in creating a new attitude both toward the traditional bookish language and toward the learned linguistic tradition, provoking changes in the functioning of particular variants of the bookish language and, ultimately, the rejection of traditional bookishness as the principal medium for the expression of cultural values.

The transformation of linguistic thought was common throughout Europe, although in various regions it proceeded differently, at different speeds, influenced by the specifics of national traditions and their starting points, and produced diverse, at times dissimilar, results. The cause of this transformative process was religious conflict, which gripped all of Europe to a greater or lesser extent and radically altered the traditional social organization of religious life; if earlier continuity of religious convictions from generation to generation had been the norm, now to a significant extent they were a

addressee may be discerned with greater or lesser clarity: the "Merilo Pravednoe" (Scale of Righteousness) was meant for rulers and judges while collections of ascetic works were for monks. However, the differentiation of addressees remained rudimentary and imprecise, as the free transfer of texts from one collection to another - say, from the "Merilo Pravednoe" into compilations of ascetic texts - testifies. The usual addressee remained the Christian people as a whole, without any further specification. As regards the most important texts - the liturgical ones - social characteristics of the addressee did not exist at all, as they were addressed to God and not to men. This is seen most clearly in liturgical polyphony (mnogoglasie), when various parts of the service are performed simultaneously by various clergymen and church servitors in order to fulfill the instructions of the typicon and not to leave out any part of the service. This turns the texts that are read and sung simultaneously into an undifferentiated hubbub as far as the congregants are concerned, but not for God, who is believed to be able to comprehend any number of texts at one time. It is indicative that in the middle of the seventeenth century sequential performance (edinoglasie) was introduced, that is, reading all parts of the service in order (cf. Zen'kovskii 1970, 112-8). This makes it comprehensible to the listener, i.e., it presumes a certain attention to the audience, and is clearly connected to the process of differentiation of addressees in bookish culture of the time. 
matter of personal involvement and individual choice. This process began in the framework of the Reformation in its various manifestations and was not extinguished by the Counter-Reformation, which gave it new stimuli. Each person's convictions became the target of opposing religious doctrines so that religious polemics and doctrinal apologetics were addressed to an ever wider audience.

Orthodox Slavdom did not remain apart from this process. The rethinking of linguistic ideas overtook Lithuanian Rus' first of all because it was directly touched by Reformation and Counter-Reformation trends. Evidence of this are the bible translations of Fransiscus Skorina, who published them so that "not only doctors and educated people will understand them but any simple and common person reading or listening can understand what is needed for his spiritual salvation" (Karskii 1921, 24). This development further led to the formation of the "simple" or "Russian tongue" (ruskaia mova) as the literary language of South-Western Rus', functioning alongside Church Slavonic (see Tolstoi 1963; Uspenskii 1983, 64f). In the seventeenth century appear the new Bulgarian translations of the "damaskins," whose language reflected the linguistic position of Damaskin Studite, who wrote in the koine glosse (common tongue), hoping to bring spiritual enlightenment to the broad masses (Dell'Agata 1984, 15-89; Demina, III, 18-9). This century also witnessed the turn to the "simple tongue" in Serbia.

As far as Muscovite Rus', the corresponding processes were more complex and less obvious. Here in the first half of the seventeenth century the idea of necessary universal religious enlightenment developed within the context of attempts at the "ecclesiasticization" ("otserkovlenie") of Russian life, the establishment of religious discipline (blagochinie) and religious statues as the norm for everyday life of the entire population (cf. Zen'kovskii 1970, 59-90). These efforts that were characteristic of the Bogoliubtsy or Zealots of Piety demanded active propaganda and intensive religious education for the masses. Such activity naturally presupposed the use of language that would be comprehensible to a wide audience. What this language was, we don't know exactly, but individual texts by Avvakum and Nasedka can give some sense of them. In the supplement to the Life of Dionisii Zobninovskii, written by Nasedka, and the Life of Avvakum significant fragments are written in a language that is almost completely devoid of specifically bookish features; the literary character of the text is signaled by the rare use of markers of bookishness. In this case the choice of the hybrid register is intentional and reflects the authors' individual polemical position (see below).

At the same time we may presume that these linguistic efforts were connected to a certain religious tradition whose general program included 
the regularization of Russian ecclesiastical culture and hanges in church customs aimed at expanding the influence of church teaching on all aspects of the people's life. Nasedka's activities may thus be connected to traditions going back to Dionisii Zobninovskii and Arsenii Glukhoi (see Jaksche 1985; Skvortsov 1890), and from them to Maksim Grek and his pupils. This tradition had to have a philological aspect, and in this connection we cannot fail to mention the evaluation of Maksim Grek's linguistic practice that is given in the works of Maksim's pupil Zinovii Otenskii. Otenskii wrote: "Maksim... thought ... that after bookish speech we have common speech. [But] I think it is an evil idea of heretics or the ignorant to liken and degrade the bookish language to [the level of] common popular speech... Maksim cannot be blamed because he did not know the Russian language thoroughly" (Zinovii Otenskii 1863, 967). Paradoxically, Maksim appears here to be initiator of the rapprochement between bookish and popular languages, although he was unquestionably far from an orientation on colloquial speech. However, in advancing the grammatical approach Maksim did not strive for the maximal distancing of the written language from the conversational. For him grammatical education that (as noted above) presumed varying levels of knowledge was primary. An uneducated person needed a "simple" text, which led to the idea of a "simple language," and this connected Maksim to the Bogoliubtsy. In the context of active religious and educational policies these potential aspects of linguistic thought were actualized, and conditioned the unique manifestation of the idea of linguistic "simplicity" in Muscovite Rus'.

The spread of the idea of linguistic "simplicity" in Slavic lands differed from the similar process in Western Europe because of differences in their initial situations. In France, England, and Germany the national languages had existed as the languages of culture long before the spread of ideas of linguistic simplicity. Latin was clearly juxtaposed to the national tongues in linguistic consciousness, and ideas of linguistic simplicity were manifested in the shifting borders of the cultural territory to which each of them was assigned. In Muscovite Rus', as for other Orthodox Slavs, Church Slavonic alone functioned as the language of culture. Therefore the idea of linguistic simplicity could not be realized by redistribution of the functions of Church Slavonic and some other language. In these conditions one of two possible developmental schemes was possible: either the functions of the separate registers of the bookish language could be redefined, with one singled out as "simple," or a new "simple" language could be created that was juxtaposed to Church Slavonic. In both instances, the creation of works in the "simple tongue" ran into significantly greater difficulties and was subject to greater restrictions than in the Western European case. 
These difficulties were conditioned by the inner contradiction that the notion of a "simple" language introduced into the Orthodox tradition. Indeed, this idea demanded the comprehensibility and accessibility of religious texts. This demand could be fulfilled fairly easily in the case of newly created texts, as they could be fashioned on the basis of some new "simple" language. But transferring this language into all spheres of cultural activity would mean a rejection of the whole earlier tradition, the entire corpus of Church Slavonic texts that had been compiled over centuries and that made up the core of Orthodox culture. If religious and cultural needs could have been satisfied by literature in the new language, the use of literature in the traditional bookish tongue would become the affair of a small number of aficionados; it would threaten its existence as a living tradition: comprehensibility of the new ran counter to the comprehensibility of the old. This conflict led to attempts to seek a compromise between tradition and the comprehensibility of the "simple" language. In different situations the result could be closer to one or the other pole, to tradition or comprehensibility; the compromise itself, however, was in all cases reflected in the functioning of the "simple" texts, limiting the polyfunctionalism of the new means of expression and superimposing a certain imprint on the structure of the "simple" language (for all the diversity of the linguistic manifestations of this simplicity).

In Muscovite Rus', that was not seriously threatened by Catholic or Protestant proselytism (which stimulated the creation of literature in the "simple" tongue, for example, in Ukraine), the need for the "simple" language was not so pressing as in Kiev, L'vov or Vilnius. Here there was no basis even for a partial rejection of the Church Slavonic tradition, and compromise clearly tended toward the pole of traditionalism. And here in the second half of the seventeenth century appeared a series of monuments that their authors considered written in the simple language. On closer inspection, however, it turns out that most of these were written in standard Church Slavonic, and the declarations about "simplicity" were purely for show. They only indicate that the authors' concern about their addressees was limited (voluntarily or due to their lack of knowledge) to the rejection of grammatical refinement, that is, the issue boiled down to the opposition between "learned" and "simple" writing that arose consequent to the spread of the grammatical approach to the bookish language (discussed above). ${ }^{16}$

\footnotetext{
16 Simeon Polotskii's Obed dushevnyi and the book called Statir, written by an unknown clergyman from the Perm diocese (Alekseev 1965; Uspenskii 1994, 196-9; Zhivov 1991; on Statir's language, see $\S$ III-3.1) are examples of this kind of "simple" language. Polotskii's linguistic practice is especially instructive. Very familiar with the Ukrainian variant of the "simple" language, in the context of Muscovy he chose a traditional variant of Church
} 
Still, there were individual texts that were declared to be "simple" that were written in a language different from standard Church Slavonic, and whose choice of register was clearly connected to the writer's reformist position. The clearest monument of this type is the 1683 Psalter of Avraamii Firsov that was translated "for easiest understanding" (udobneishego radi razuma) into "our simple Slavonic tongue... without any ornamentation" (Tselunova 1989, 28). The inconsistent use of the perfect with auxiliary verb, aorist and imperfect, gerunds in -me, etc. (Tselunova 1985; Tselunova 1988), testify to the hybrid nature of this translation. Understandably, the choice of the hybrid language in this case was purposeful and represents a reforming innovation insofar as this was an extremely important book for Orthodox piety and universally known in its traditional form (i.e., as a text in standard Church Slavonic). The new version was juxtaposed to the old as comprehensible to incomprehensible or as "simple" to complex. It is telling that Firsov's translation was banned by Patriarch Ioakim, who presumably saw it as a threat to the Orthodox tradition. From his point of view the balance between traditionalism and comprehensibility was evidently violated in favor of comprehensibility, which quite clearly describes the specific character of the problem of the "simple" tongue in Muscovite Rus'.

Another stimulus for the choice of nonstandard register evidently also existed. When a work was of polemical character and had to convey the authors' personal convictions and the pathos of his individual achievement, the standard bookish language, which could be perceived as the means for conveying the single and supra-personal truth (see Upsenskii 1983, 4950), was inappropriate. ${ }^{17}$ However, the majority of polemical tracts of the seventeenth century were written in the traditional bookish language; see if only the "Objection or the Ruin of Humble Nikon, by God's Grace the Patriarch. Against the Questions of Boyar Simeon Streshnev" [Vozrazhenie ili razorenie smirenago Nikona, Bozheiu milostiiu pariarkha. Protivo voprosov boiarina Simeona Streshneva] (RGADA, f. 27, no. 140, ch. III), Simeon Polotskii's Zhezl pravleniia [Crozier Staff of Rule] (1667) or Afanasii Kholmogorskii's Uvet dukhovnyi [Spiritial Admonition] (1682).

Slavonic as its equivalent, clearly preferring tradition to comprehensibility, at the same time presumably counting on Moscow's relatively high level of Church Slavonic culture.

17 The action of this stimulus is quite visible in the confessional polemics in Ukraine in the late sixteenth-early seventeenth century. Thus Ivan Vishenskii, asserting the unchanging importance of the Church Slavonic language, its holiness and the need to study it, writes about this in the "simple tongue" (prostaia mova -on Vishenskii's ideas about language see Gröschel 1972, 10-14, 18-26). A hundred years later Mikhailo Andrella follows the same pattern (Petrov 1921, 241). 
These treatises were conceived not as defenses of individual points of view but as exposing the obvious incompatibility of the opponent's perspective with supra-personal and generally understood dogma. However, in those cases when the author's goal was to convey personal, subjective conviction, the rejection of standard Church Slavonic was nevertheless appropriate. This may have been the situation with the sermons of Ioanna Neronov ${ }^{18}$ and Avvakum and partially with the latter's other writings, and this factor could later influence Old Believer polemical literature.

Given the necessity to compromise between traditionalism and "simplicity" the hybrid register offered an ideal solution that combined both of these features. The move from the standard to hybrid register was understandably perceived as a simplification. As has been noted, in the linguistic consciousness of Slavic bookmen the bookish language was connected to a limited set of markers of bookishness. Their consistent and regularized use, characteristic of the standard register, indicated mastery of the bookish language and linguistic refinement, while the use of the hybrid language indicated common, unskilled proficiency, characteristic of someone who was not very well versed in book culture. "Not learned in grammatical reason, but being a simple man I wrote with my own hand," explained the elder Avramii in his notebooks of 1696 (Baklanova 1951, 150), and these notebooks offer a typical example of the hybrid language. Given this attitude, the change from the first to the second type of using markers of bookishness was definitely supposed to be perceived as simplifying the language, as a step toward greater comprehensibility. At the same time, insofar as the language preserved markers of bookishness, this change did not take linguistic usage beyond the bounds of Church Slavonic and did not signify a break with tradition.

In these conditions it is natural that in the history of all literary languages of Slavia Orthodoxa the early stages of the movement toward a "simple" language are characterized by the use of the hybrid language in this capacity (cf. Zhivov 1988, 77-8). As we have seen in the case of Avraamii Firsov's translation of the Psalter, Muscovite Rus' was no exception. The hybrid register was used in the Life of Archpriest Avvakum (see the materials characterizing his language: Cocron 1962; Chernov 1977; Chernov 1984; Timberlake 1995), which was undoubtedly connected to the author's

18 See the description of Neronov's preaching in the "Zhitie Ioanna Neronova" [...] (Materialy, I, 257). We cannot judge the concrete linguistic parameters of Neronov's sermon, but it clearly reflected a new linguistic consciousness that was undoubtedly tied to his religious stance; notably, Ioann not only preaches himself but also calls his flock to universal preaching, which clearly fits into the reformist paradigm. 
reformist attitude toward his audience. The consistency of using hybrid variants in the capacity of a "simple" or "comprehensible" written language was directly related to the strong desire of the given social group to retain ties to traditional culture. It was precisely the determination not to break with centuries'-old cultural and linguistic tradition that imposed limitations on the development of literary languages of the new type; "simple" languages were either compromises in terms of their structural organization (hybrid languages seen as "simple") or they remained secondary citizens in the functional regard. In order to change this situation, a culturological stimulus was needed - the decision to create a new culture of the secular type that would radically break with the past and allot traditional literature a markedly subordinate place in socio-cultural development.

The historical-cultural and cultural-linguistic development connected with ideas about the "simplicity" of the written language created the prerequisites for a radical break of this type, although it by no means preordained it. Indeed, the conscious use of a variety of "simple" languages and the correlation between varieties of the bookish language with various degrees of grammatical proficiency were what formed linguistic consciousness. These processes, however limited they may have been in social terms, made it possible to look at the traditional bookish language from a new perspective. In opposition to the "simple" tongue, this language became "not simple," in opposition to grammatically elementary language it was seen as not elementary, and the striving of the "simple" language to be comprehensible pigeonholed it as "incomprehensible." For centuries Church Slavonic had been seen as a universal literary language that served needs of culture as a whole. With the appearance of "simple" variants the significance of the traditional Church Slavonic language within the cultural and linguistic value system was asserted primarily on the basis of its ecclesiastic and religious usage and its learned grammatical cultivation. In this context the complete rejection of Church Slavonic was associated with the rejection of Orthodoxy and its grammatical educational system that functioned completely within the framework or religious culture. From a certain perspective this could assign Church Slavonic the attribute of clericalism and lead to its rejection as a "clerical" language. However, the appearance of such a perspective presupposes the secularization of culture. And indeed the cultural and linguistic situation described above "began to experience shocks only when secular literature began to lay claim to the role of supreme literature" (Vinokur 1983, 258). At the same time the very character of the new cultural and linguistic situation was dependent on the nature of the secularizing process, for which reason the specifics of its introduction into Russia were a 
significant influence on the way the literary language of the new type came into being.

\section{The Secularization of Culture, Its Specifics in Russia, and Its Significance for Rethinking Linguistic Usage}

The process of cultural secularization was begun in Europe during the Renaissance, not because there was no secular culture before the Renaissance, but because until that time it had not presumed an independent role. This was a revolutionary moment, although it had organic roots in the past, first of all in the system of secular education that medieval Europe inherited from the Roman Empire; however weak this may have become, and however much an accessory to religious education, it remained capable of regeneration, and became organic soil for secularization. The Renaissance's continuity in this area was clearly marked, for example, in the character of its assimilation of the classical rhetorical tradition and of classical mythology (see Seznec 1961; Zhivov and Uspenskii 1984). A particular instance of this continuity is the fact that secular culture was by no means alien to connections with the Latin linguistic tradition; in this respect it wasn't opposed to religious culture. For this reason the process of secularization did not have a direct connection to the question of language. Secularization, of course, could serve as one of the factors influencing the redistribution of spheres of usage between Latin and the new national literary tongues, but the conception of a particular subject as specifically religious or secular by no means predetermined the language in which that subject was described. The democratizing of education significantly influenced the new distribution, but at least up to the eighteenth century democratization was more characteristic of religious than secular culture.

The starting points for the Eastern Slavs as a whole and Muscovite Rus' in particular were completely different. Here secular culture had no organic roots at all, and in this Russia differed not only from the West, but also from Byzantium. The issue then was not the specifics of Eastern Christianity, as is sometimes asserted (e.g. Trubetskoi 1973, 19-28), but in the special nature of the reception of Christian culture by the Eastern Slavs. It would be a mistaken exaggeration to assert that all spiritual interests of medieval Russian society were exclusively religious, that the life of the court or the patrimony of a boyar were but light-weight versions of monastic 